\title{
The world market for soybeans: price transmission into Brazil and effects from the timing of crop and trade
}

\author{
Mario A. Margarido \\ Scientific Researcher at the Instituto de Economia Agrícola \\ Frederico A. Turolla \\ Lecturer and researcher at the ESPM and the FGV-SP \\ Carlos R. F. Bueno \\ Technical Assistant of the Direction \\ of the Instituto de Economia Agrícola
}

\section{Key words}

soy, elasticity of price

transmission, time series

econometrics.

JEL Classification Q17, C32.

\section{Palauras-chave}

soja, elasticidade de transmissão de preços, econometria de séries temporais.

Classificação JEL Q17, C32.

\section{Abstract}

This paper investigates the price transmission in the world market for soybeans using time series econometrics models. The theoretical model developed by Mundlack and Larson (1992) is based on the Law of the One Price, which assumes price equalization across all local markets in the long run and allows for deviations in the short run. The international market was characterized by three relevant soybean prices: Rotterdam Port, Argentina and the United States. The paper estimates the elasticity of transmission of these prices into soybean prices in Brazil. There were carried causality and cointegration tests in order to identify whether there is significant long-term relationship among these variables. There was also calculated the impulse-response function and forecast error variance decomposition to analyze the transmission of variations in the international prices over Brazilian prices. An exogeneity test was also carried out so as to check whether the variables respond to short term deviations from equilibrium values. Results validated the Law of the One Price in the long run. In line with many studies, this paper showed that Brazil and Argentina can be seen as price takers as long as the speed of their adjustment to shocks is faster than in the United States, the latter being a price maker.

\section{Resumo}

Este trabalho investiga a transmissão de preços no mercado mundial de soja usando econometria de séries de tempo. O modelo teórico desenvolvido por Mundlack and Larson (1992) é baseado na Lei do Preço Único e supõe que os preços se equalizam ao longo de todos os mercados locais no longo prazo, permitindo-se desvios transitórios no curto prazo. O mercado internacional foi caracterizado através de três preços relevantes: Rotterdam, Argentina e Estados Unidos. O trabalho estima a elasticidade de transmissão desses preços aos preços no Brasil. Foram realizados testes de causalidade e de cointegração para verificar se bá relação de longo prazo entre as variáveis. Foi também calculada a função de resposta a impulso e a decomposição da variância dos erros para avaliar a transmissão de precos internacionais aos preços brasileiros. Aplicou-se um teste de exogeneidade para verificar se as variáveis respondem a desvios de curto prazo em relação aos valores de equilíbrio. Os resultados confirmaram a validade da Lei do Preço Único no longo prazo. Em linha com vários trabalhos, este artigo mostron que Brasil e Argentina podem ser vistos como tomadores de preços no mercado internacional, tendo em vista que a velocidade de ajuste de seus preços em resposta a choques é maior que a verificada para os preços dos Estados Unidos, que são formadores de preço. 


\section{1_Introduction}

Soybean and its derivatives enter as key inputs in several segments of the agribusiness chain. According to Freitas et al. (2001, p. 2),

this commodity is one of the most widely traded agricultural products in the world, probably because of the variety of forms of consumption, which range from food (buman and animal) to the pharmaceutical and steel industries. This diversity is possible because the soybean processing industry produces by-products, soymeal and oil, which constitute important inputs for different industrial sectors.

The international market for soybeans has an interesting feature of a strong degree of concentration on both the supply and demand sides. According to data from USDA (2003), 79.87\% of the total world production in the period between 1994/1995 and 2002/2003 took place in three countries, the United States (44.85\%), Brazil (21.71\%) and Argentina (13.30\%). These three countries were also the world's leading exporters, accounting together for $90.50 \%$ of the 44.32 millions of tons produced in the same period. The United States was the leading exporter with $56.85 \%$ of the total, followed by Brazil (24.10\%) and Argentina (9.54\%).
On the demand side, the major export destination during the same period was the European Union (EU) with 36.98\% of the total, where soy meal is basically used for animal feed. China is the second largest market for soybean imports, with $16.22 \%$. Together, the European Union and China account for $53.20 \%$ of world imports. It is noteworthy that the importance of China in the international market started to grow only late in the 90's, when its imports jumped from 3.85 in 1998/1999 to 10.10 million metric tons in $1999 /$ 2000, according to Oilseeds (1995/2003). As the Chinese economy maintained a strong pace of growth, its imports grew further to 21.42 million metric tons in 2002/2003 (Oilseeds, 1995/2003).

Being the second largest producer and exporter of soybeans, Brazil relies strongly on the soy chain as a source of foreign currency receipts in the current account of its balance of payments. According to data from Conab (2004), in the year 2003 Brazil exported US\$73.1 billion in goods, of which $41.9 \%$ or US $\$ 30.6$ billion were products of the agribusiness chain. The soy chain ${ }^{1}$ accounted for $11.1 \%$ of total Brazilian exports, with annual receipts of US\$ 8.1 billion. These data also reveal that the soy chain plays a key role

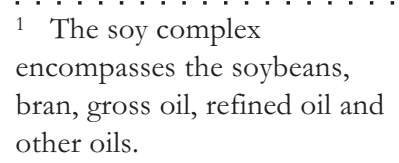


not only as a source of foreign currency receipts for Brazil but also as a major source of income among the several segments of the country's domestic agribusiness chain.

Given the importance of the soy chain, several studies using time series were performed to analyze the formation of soybean prices in Brazil. Results of some of these studies are described in the remainder of this section.

Aguiar and Barros (1991) pursued a test strategy based on the Sims' causality test to discover elasticities of price transmission and found that international prices led domestic prices, but the time lag for price transmission was found to be between 1 and 4 months. They also found that domestically, wholesale prices tend to lead other prices. The authors also searched for asymmetry using Houck's asymmetry test and found evidence that the various market levels respond more to price increases than to decreases. They outlined some of the reasons behind this asymmetry, including inflation expectations, relatively small price-elasticity of the demand for oil and, for international price transmission, Brazilian trade policy. The latter changed over the nineties so that one should expect that such asymmetry would subside from then on.
Pino and Rocha (1994) evaluated the transmission of Chicago Board of Trade (CBO'T) quotations to the prices of soybeans at industry and farm levels in Brazil. In general terms, these authors reached the conclusion that domestic soybean prices in Brazil are strongly influenced by the movement of CBOT prices. The latter determines the quantity supplied in Brazil and also affects prices of domestic byproducts (grain and soymeal).

Margarido and Sousa (1998) analyzed the transmission of soybean prices to prices in Brazil and in Paraná. The study found that changes in CBOT quotations are only partially transmitted, but without time lags, to prices at the farm level, for Brazil as a whole and for Paraná. Such low elasticity of price transmission was found to be apparently related to the strategies pursued by crushers, which choose the final destination of the soybeans taking into account the relationship between international and domestic prices. Besides, domestic consumption of soybean derivatives is relevant since soy meal is used to feed poultry while oil is widely consumed internally because of its price advantage against alternatives such as rape seed and sunflower. These factors, plus the cost of producing in 
Brazil, possibly influence the behavior of the elasticity of price transmission, making it smaller than unity.

Margarido et al. (1999) broadened the scope of soy chain studies by measuring the elasticity of price transmission involving the CBOT, the prices at the Port of Rotterdam and domestic prices in Brazil and Argentina. They found that variations in Rotterdam prices are transmitted more intensely and faster to domestic prices in Brazil and Argentina than variations at CBOT. Since Rotterdam prices are spot price for imports destined to the European Union and CBOT prices are future prices that reflect supply conditions, these results suggest that demand prices play a more significant role in the formation of Brazilian and Argentine domestic prices than supply prices. Another finding of this study was that Argentine prices are more sensitive than Brazilian prices to variations in international prices, what probably reflects the specific characteristics of the two markets. Brazil has a relatively more important domestic consumption market, while Argentina sends out the bulk of its production to international markets, being more exposed to those variations.

Machado and Margarido (2001), using a different methodology based on
Granger Causality tests, reached a similar conclusion: that Brazilian and Argentine domestic prices are more sensitive to variations in Rotterdam than in CBOT.

Mafioletti (2001) analyzed price formation (grain, meal, oil) between market levels (producer, wholesale, consumer), in both the domestic and external markets, and also between the major producing and consuming areas in the domestic Brazilian market. The analysis was carried for two periods, the first from January 1982 to December 1989, and the second from January 1990 to December 1999. By performing separate analyses for the two periods, it was possible to assess the effects of major changes in the Brazilian trade policy that took place over the nineties, such as economic openness and trade liberalization itself. Chicago Board of Trade (CBOT) prices were used. Granger causality tests were carried out to discover the direction of causality. Equations for the elasticity of price transmission were estimated. Results suggested instantaneous transmission or small lags of up to one month. Such velocity of price transmission suggests that the markets of the soy complex show efficiency. The study also pointed out that from the nineties onwards there was an increase in the degree of interdependence of Brazilian prices in 
the soy complex compared to

international prices.

Margarido et al. (2001) analyzed price transmission in the grain market between the Port of Rotterdam and Brazil for July 1994 - September 2000. A Vector Error Correction model was estimated with and without imposing restrictions on parameters. Results suggest that in the short term, grain prices in Brazil tend to eliminate more rapidly any transitory disequilibrium relative to Rotterdam prices. In the long term, price variations in Rotterdam as well as exchange rate changes are fully transmitted to prices in Brazil, thus confirming the Law of One Price in that market. Soybean prices in Brazil are therefore totally dependent on international prices.

In a nutshell, the literature presents evidence that price transmission is either rapid or instantaneous (little or no time lag) between the several segments of the soy complex. The market then has little information asymmetry, being efficient. Another relevant factor is the strong dependence of Brazilian prices on international prices.

\section{2_Objectives}

The objective of this study was to quantify the elasticity of price transmission $^{2}$ in the international market for soybeans, involving Cost Insurance and Freight $(\mathrm{CIF})^{3}$ prices at Rotterdam, Free on Board (FOB) ${ }^{4}$ prices in Brazil, Free on Board (FOB) in Argentina and U.S. NO.1 Yellow ${ }^{5}$ Cash Central Illinois (USA) for the period between October 1995 and October 2003. Causality and cointegration tests were performed in order to identify whether there is a significant long-term relationship among
2 Barros and Burnquist (1987, p. 178) note that the "elasticity of price transmission refers to the relative variation in the price at a market level in relation to the variation in the price at another level, keeping equilibrium in these two levels after the initial shock in each of them". Although this study involves different countries (Brazil, The Netherlands,
Argentina and the United

States, the analysis was carried out in the same market in all countries (soybeans), but at different levels (soybeans FOB Brazil, Argentina and United States and CIF Rotterdam), thus the above definition applies.

3 CIF prices: all expenses, including freight and insurance, up to the port of destination are at seller's expense.
4 FOB prices: all expenses up to the delivery of the merchandise on board of the ship indicated by the buyer, in the port of origin, are at sellers' expenses.

5 According to the United States Standards for Soybeans, there are two classes of soybeans, mixed and yellow soybeans, the latter being "that have yellow or green seed coats and which in cross section, are yellow or have yellow or have a yellow tinge, and may include not more than 10.0 percent of soybeans of other colors". Soybeans may be classified in grade requirements ranging from 1 to 4 , according to minimum test weight per bushel, maximum percent limits of damaged kernels and maximum count limits of other materials. Number 1 meets the highest standards. 
these three variables. The impulseresponse function ${ }^{6}$ was also calculated and forecast error variance decomposition to analyze the transmission of variations over time in the Port of Rotterdam, Argentina and United States prices over Brazilian domestic prices. An exogeneity test was also carried out to check whether the variables respond to short term deviations from equilibrium values.

\section{3_ Theoretical model}

Mundlack and Larson (1992) developed the theoretical model used in this paper. This model shows how variations in external prices transmit to domestic prices $^{7}$. Based on the Law of One Price $^{8}$, the domestic price of soybeans can be written as a function of the international price of the commodity, the nominal exchange rate and the specific trade policy. ${ }^{9}$ Algebraically, this model ${ }^{10}$ can be stated as follows:

$P_{i t}=P_{i t}^{*} E_{t}$

where $P_{i t}$ is the domestic price of the $i$ product at period $t ; P_{i t}^{*}$ is the international price of the $i$ product at period $t ; E_{t}$ is the nominal exchange rate at period $t$.

Multiplying both sides of (1) by $1 / E_{t}$, we have:

$P_{i t}^{u s}=P_{i t}^{*}$

where $P_{i t}^{u s}$ refers to domestic prices of product $i$ taken in US dollars in time $t$. Thus, in this paper the term $P_{i t}^{u s \$}$ stands for the price of the soybeans in Brazil, however in US dollars.

The model presented by Mundlack and Larson (1992) can be modified to incorporate specific elements from the international market
6 According to Barros (1990, 7 In the absence of

p. 13) the concept of impulse elasticity measures the variation of "variable $i$ over variable $j$ as a rate of the impact experienced by variable $j$ and the impact experienced by variable $i$. The word elasticity applies strictly when variables are measured in logarithmic scale". intervention, domestic prices equal international prices.

8 Krugman and Obstfeld (1997) note that although Purchasing Power Parity is similar to the Law of One Price, there is a difference between them. While the latter applies to a single product, the first refers to the general price level reflecting the prices of all products that compose a bundle of goods taken as a reference. However, if the Law of One Price is valid for every product in this bundle, then the Law of One Price is equivalent to the Purchasing Power Parity.

9 Since this paper is not concerned with trade policies, this variable was not included in the model.

10 This model does not take into account qualitative differences between the products and the transport costs, storage, or the prices of the nontradable domestic inputs. 
11 Several studies reached the conclusion that the price of soybeans in Brazil is influenced by its prices in the European Union and the United States; this means that the direction of causality is uni-directional. For Argentina, it is relevant that its harvest reaches the market with a lag of one to two months as compared to the Brazilian harvest.

Thus, the estimates for the Argentine harvest may influence prices in Brazil, as one takes into account that the international market for soybeans is highly concentrated. The United States, Argentina and Brazil account together for roughly $80 \%$ of world soy production, causing a high correlation between prices in these three countries. of a given product. In the long run, the Law of One Price states that domestic prices tend to equal world market prices for any given product. In other words, the elasticity of transmission has to be unity. In such a context, the world market price can be written in the form of a multiplication operator, since the objective of this paper is to estimate the relevant elasticities of price transmission:

$P_{i t}^{*}=\prod_{i=1}^{n} \prod_{j=1}^{n} W_{i}^{j} P_{i t}^{j}$

where the subscript index $i$ represents product, while the subscript $j$ is for the country and $W$ is the respective weight in the weighted geometric average that composes the international price.

Taking the case of the international soy market, its international price can be decomposed as follows:

$P_{i t}^{*}=W_{i}^{\mathrm{Rot}} P_{i t}^{\mathrm{Rot}} W_{i}^{A r g} P_{i t}^{A r g} W_{i}^{U S A} P_{i t}^{U S A}$

where $P_{i t}^{\text {Rot }}$ is the price of the soybeans in Rotterdam in dollars; $P_{i t}^{A r g}$ is the price of the soybeans in Argentina and $P_{i t}^{U S A}$ is the price of the soybeans in the United States. Two assumptions are necessary at this stage. First, we must assume that the sum of the three weights equals unity in equation 1c so that equality holds in respect to equation 1c. The second assumption is that the weights in the equation have identical values, given the characteristics of the international market for soybeans. Since few countries hold a sizable share of the world supply, one should expect to find a high correlation among its prices, provided the arbitrage process is functioning properly as it is described by the Law of One Price.

An error term $(u)$ was added to the equation to capture possible deviations from variables not included in the model. Writing equation (1a) in the logarithmic form, we obtain:

$p_{i t}^{U S \$}=p_{i t}^{*}+u_{i t}$

or alternatively, through decomposition of the international price. ${ }^{11}$ Thus,

$p_{i t}^{U S \$}=p_{i t}^{R o t}+p_{i t}^{A r g}+p_{i t}^{U S A}+u_{i t}$

where $\mathrm{u} \sim \operatorname{IID}\left(\mu, \sigma^{2}\right)$ and $\mathrm{E}\left(p^{*} \mathrm{u}\right)=0$, from equation 2 meaning that $u_{i t}$ shows no correlation with the other explicative variables of the model. The simplest model thus assumes domestic prices of a single product to be a function of its respective international price and the disturbance term. From equation 2 the following model can be estimated: 
$p_{i t}^{U S \$}=\alpha+\beta p_{i t}^{*}+\varepsilon_{i t}$

where $\alpha$ is a constant (intercept) and $\beta$ is assumed to be unity. The $\beta$ coefficient is then the elasticity of the domestic price in US Dollars against its international price, i. e., it is an elasticity of price transmission. When its value is unity, variations in the international price are fully transmitted to domestic prices. On the other hand, when the $\beta$ value is zero, variations in international prices do not lead to any response in domestic prices, the domestic economy being completely closed. The most common situation is when $\beta$ lies between zero and one, reflecting a specific trade policy adopted by the country or any sort of trade restriction imposed on the market.

The model shown in equation 3 can be restated to present the international price of soybeans by country:

$p_{i t}^{\text {USS }}=\alpha+\beta_{1} p_{i t}^{\text {Rot }}+\beta_{2} p_{i t}^{\text {Arg }}+\beta_{3} p_{i t}^{\text {USA } A}+\varepsilon_{i t}(3 \mathrm{a})$

Equation 3a has an advantage over equation 3 , namely that it allows direct estimation of the respective elasticities of price transmission. In this case we assume that $\beta=\beta_{1}+\beta_{2}+\beta_{3}$. When $\beta=1$, then the Law of One Price holds, meaning that price variations in the international market ${ }^{12}$ for soybeans are fully transmitted to the domestic price in Brazil, denoting unity elasticity of price transmission. Thus, in this case $\beta_{1}+\beta_{2}+\beta_{3}=1$. Another hypothesis to be tested is that these four markets are integrated, thus price transmission flows without restrictions between the markets involved, or, the arbitrage system equalizes the prices in all markets in the long run. Thus, one should expect that the three coefficients be identical $\beta_{1}=\beta_{2}=\beta_{3}$.

\section{Dataset and methods}

\section{1_Dataset}

For this paper, four time series with monthly observations were created: Cost, Insurance and Freight (CIF) prices at the Port of Rotterdam $(\mathrm{ROT}),{ }^{13}$ Free on Board (FOB) prices in Brazil (BR), FOB prices in Argentina $(A R G)$ and U.S. NO.1 Yellow Cash Central Illinois (USA). Basic data on soybean prices were obtained from Oilseeds (Oct. 1995/Oct. 2003).

Since all variables were used in logarithmic form, coefficients can be directly read as elasticities. Logarithms of variables ROT, BR, $A R G$ and $U S A$ were named $L R O T, L B R, L A R G$ and LUS A respectively.

\footnotetext{
12 International market stands for Rotterdam, United States and Argentina.

13 Refers to the notation of the variables used along the paper.
} 
$\cdots \cdots$

14 The definition

of cointegration can be found in Engle and Granger (1991).

\section{2_ Methods}

The order of integration of the variables was determined with the Augmented Dickey Fuller (ADF) test in accordance with Dickey and Fuller (1981 and 1979). Critical values were obtained in Mackinnon (1991) while critical values for the joint tests are from Dickey and Fuller (1981).

Granger's causality tests according Granger (1969) were used to verify the causality direction among the variables.

The cointegration test ${ }^{14}$ sought to detect long-term relationship among the variables. This paper used the Johansen cointegration test following Johansen and Juselius (1990), with critical values from Osterwald-Lenum (1992). An Error Correction Model (ECM) was also estimated. According to Banerjee (1993, p. 139), the ECM allows for a link between the short and long term dynamics as it provides a methodology for modeling both in levels and in differences. Consequently, the ECM models simultaneously predict the short-term dynamics of adjustment (variations) and the long term (levels). Other methodological aspects that need to be emphasized include the incorporation of restrictions over the short term parameters $(\alpha)$ and long term parameters $(\beta)$ in the vector error correction model, besides the usage of a decomposition of the forecast errors and impulse-response function for the analysis of the price transmission dynamics over time in the international market for soybeans, and also exogeneity tests to check whether variables react to short term deviations from equilibrium.

\section{5_Analysis of the results}

Unit root testing requires choosing the number of lags in each test so as to eliminate autocorrelation in the residuals. Based on the Schwarz Information Criterion, variable $L R O T$ in level entered with two lags while in difference there was no need for lags. For LBR in level, the Criterion showed its minimum value for a second order autoregressive model, so that two lags were used in the respective unit root test. Variable $L B R$ in differences showed a first-order autoregressive model. Thus, the unit root test procedure was carried out with only one lag. For variable $L A R G$ in level, the information criterion reached its lower value for an autoregressive model of order 2. In this case, we used two lags in the unit root test. For the same variable, differentiated from order one, 
the information criterion reached its lower value for a moving average model of order $1,{ }^{15}$ leading to the use of the data dependent method in the identification of the number of lags, ${ }^{16}$ which resulted in six lags. Finally, for variable LUS $A$ in level, an autoregressive model of order 2 was identified, as shown by the result of the information criterion, implying two lags. For variable LUS A differentiated, the information criterion detected a moving average model of order one, leading to the use of the data dependent method as was the case with variable $L A R G$ differentiated. Thus, results from the data dependent method led to the inclusion of five lags in its respective unit root test (Table 1).

The variables presented unit root when tested in levels but became stationary in differences considering all the three significance levels that were adopted for each statistics. Table 2 shows that the first order differentiation produces stationary patterns for all variables, thus they are all difference-stationary, integrated of order one $[I(1)]$.

Table 1_ Determination of the number of lags for the ADF-type unit root tests to variables "LBR", "LROT", "LARG" and "LUSA" (sample October 1995 - October 2003) using the Schwarz Information Criterion (BIC)

\begin{tabular}{|c|c|c|}
\hline Variable & Minimum Schwarz Criterion Value & $\begin{array}{l}\text { Lags effectively used } \\
\text { in the ARMA model }\end{array}$ \\
\hline$L B R^{1}$ & $\mathrm{BIC}(2,0)=-6.05439$ & Two lags \\
\hline$\nabla L P B R^{2}$ & $\operatorname{BIC}(1,0)=-6.07525$ & One lag \\
\hline$L_{R O T}$ & $\mathrm{BIC}(2,0)=-6.0484$ & Two lags \\
\hline$\nabla$ LROT $^{2}$ & $\mathrm{BIC}(0,0)=-6.0789$ & No lag \\
\hline$L A R G^{1}$ & $\mathrm{BIC}(2,0)=-5.86409$ & Two lags \\
\hline$\nabla L A R G^{2}$ & $\mathrm{BIC}(0,1)=-5.88669$ & Six lags ${ }^{3}$ \\
\hline LUS $A^{1}$ & $\mathrm{BIC}(2,0)=-5.95719$ & Two lags \\
\hline$\nabla L U S A^{2}$ & $\mathrm{BIC}(0,1)=-5.96695$ & Five lags ${ }^{3}$ \\
\hline
\end{tabular}

(1) variable in level;

(2) variable in difference;

(3) data dependent method as described by Perron (1994).

Source: Basic data from Oilseeds (Oct. 1995 - Oct. 2003).

15 A moving average model small-order can be written in the form of an autoregressive model of high order. Given that data are of monthly frequency, we used initially twelve lags.

16 Details on the data dependent method are presented in Perron (1994). 
Table 2_Results from Augmented Dickey Fuller (ADF) ${ }^{1}$ unit root tests to variables "LBR", "LROT", "LARG" and "LUSA", October 1995 to October 2003

\begin{tabular}{|c|c|c|c|c|c|c|}
\hline Variable & $\tau_{\tau}$ & $\phi_{3}$ & $\tau_{\mu}$ & $\phi_{1}$ & $\tau$ & Order of Integration \\
\hline$L B R^{2}$ & 0.17 & 1.72 & -1.10 & 0.66 & 0.28 & $\mathrm{I}(1)$ \\
\hline$\nabla L B R^{3}$ & $-5.61^{4}$ & $16.12^{4}$ & $-5.29^{4}$ & $14.05^{4}$ & $-5.32^{4}$ & $\mathrm{I}(0)$ \\
\hline $\mathrm{LROT}^{2}$ & -0.25 & 1.44 & -1.33 & 0.88 & 0.00 & $\mathrm{I}(1)$ \\
\hline$\nabla L R O T^{3}$ & $-8.12^{4}$ & $33.03^{4}$ & $-7.96^{4}$ & $31.66^{4}$ & $-8.00^{4}$ & $\mathrm{I}(0)$ \\
\hline$L A R G^{2}$ & -0.20 & 1.33 & -1.22 & 0.75 & 0.03 & $\mathrm{I}(1)$ \\
\hline$\nabla L A R G^{3}$ & -3.695 & $7.18^{5}$ & $-3.12^{5}$ & $4.91^{5}$ & $-3.15^{5}$ & $\mathrm{I}(0)$ \\
\hline$L U S A^{1}$ & -0.36 & 1.18 & -1.27 & 0.81 & -0.03 & $\mathrm{I}(1)$ \\
\hline$\nabla L U S A^{2}$ & $-4.70^{4}$ & $11.52^{4}$ & $-4.16^{4}$ & $8.66^{4}$ & $-4.18^{4}$ & $\mathrm{I}(0)$ \\
\hline
\end{tabular}

(1) critical values for, $\tau_{\tau}, \tau_{\mu}$ e $\tau$ obtained as described by Mackinnon (1991), respectively $-3.1539,-2,5826$ and -1.6175 at $10.0 \%$ level, and $-3.4566,-2.8915$ and -1.94345 at $5.0 \%$ level, and $-4.056,-3.4993$ and -2.5873 at $1.0 \%$, level, while critical values for $\phi_{3}$ and $\phi_{1}$ were directly obtained from Dickey and Fuller (1981) and are equal to 5.47 and 3.86 at $10.0 \%$ level, and 6.49 and 4.71 at $5.0 \%$ level, and 8.73 and 6.70 at $1.0 \%$ level;

(2) variable in level;

(3) variable in difference;

(4) significant at $1.0 \%$ level;

(5) significant at $5.0 \%$ level;

(6) significant at $10.0 \%$ level.

Source: Basic data from Oilseeds (Oct. 1995 - Oct. 2003).

Prior to proceeding with causality tests, it was necessary to choose the number of lags. In this exercise the Akaike information criterion was used as presented by Akaike (1976). The minimum value was obtained with an autoregressive model of order 2. Two lags were used in the causality test.

Causality tests showed that the null hypothesis (H0), LBR does not cause
LROT, LARG and LUSA, cannot be rejected, meaning that the probability of incurring in Error Type I (to reject the null hypothesis when it is true) is below the level of significance of $5 \%$, thus the soybean price in Brazil does not influence the behavior of the international soybean price, which is represented by Rotterdam, Argentina and United States prices. This result was 
in line with expectations, as several studies have shown that Brazil, although an important producer and exporter of soybeans, behaves as a price taker in the world market. In turn, the null hypothesis that the international price for soybeans, here represented by variables LROT, LARG and LUSA does not cause $L B R$ is rejected, as the probability of incurring in Error Type I (to reject $\mathrm{H} 0$ when it is true) is much higher than the significance level of $10.0 \%$, more precisely $70.57 \%$. Again. as expected, the international price of the soybean influences the price of this commodity in Brazil, meaning the direction of causality is unidirectional. This result is in line with several studies that evaluated this price relationship (Table 3 ).

Another important procedure before the cointegration test is the determination of which of the five cases presented by Johansen and Juselius (1990) and Johansen (1995) should be adopted. The underlying reason is that when estimating the Vector Error Correction Model (VEC) from the Vector Autoregressive Model (VAR) the deterministic terms of the VEC may differ from those of the VAR. More precisely, when a deterministic cointegration relationship exists, the deterministic terms of the VAR model will not be present in the VEC. On the other hand, should the relationship be a stochastic cointegration, the deterministic terms appear in the VEC embedded in the error correction term or as an independent term in the VEC. Case 2 was chosen through visual inspection.

\section{Table 3_ Granger Causality Test results for variables "LBR”, “LROT", “LARG” and "LUSA”,} October 1995 to October 2003

\begin{tabular}{|c|c|c|c|c|}
\hline Test & Null hypothesis & $\chi^{2}$ test & Degrees of freedom & Probability \\
\hline 1 & $\begin{array}{l}\text { LROT, LARG, LUSA does not } \\
\text { cause LBR }\end{array}$ & 13.79 & 6 & 0.0321 \\
\hline 2 & $\begin{array}{l}\text { LBR does not cause LROT, } \\
\text { LARG, LUSA }\end{array}$ & 3.79 & 6 & 0.7057 \\
\hline
\end{tabular}

Source: Basic data from Oilseeds (Oct. 1995 - Oct. 2003). 
.

17 More details on interrelation between results of cointegration tests and the use of VAR models (in level or differences) or VEC can be found in Harris (1995).
The Johansen cointegration test found that at the $5.0 \%$ level, one cannot reject the null hypothesis that there is no cointegration vector against the alternative hypothesis that there is one cointegration vector. The following step was to test the null hypothesis that there is one cointegration vector against the alternative hypothesis that there are at least two cointegration vectors. Again, the null hypothesis was rejected at the $5.0 \%$ level, since the calculated value of the $\lambda_{\text {trace }}$ statistics is higher than the respective critical value (Table 4$)$. Thus, we conclude that there are two cointegration vectors. Another relevant aspect is that the eigenvalues lie inside the unit circle. According to Johansen (1995), this means that the type of non-stationarity presented by these variables in level can easily be removed through a difference operator, i. e., confirming that the variables are difference-stationary (DS). Since the number of cointegration vectors is smaller than the number of variables (reduced rank), the chosen model is the Error Correction Model (VEC) instead of the Vector Autoregressive Model (VAR). ${ }^{17}$

Table 4_Results of Case 2 for the Johansen cointegration test on statistics $\lambda_{\text {trace }}$, variables "LBR", "LROT", "LARG" and "LUSA", October 1995 to October 2003

\begin{tabular}{|c|c|c|c|c|c|c|}
\hline H_O & H_1 & Eigenvalue & $\lambda_{\text {trace }}$ & $\begin{array}{l}\text { Critical } \\
\text { Value }^{1}\end{array}$ & $\begin{array}{c}\text { Error } \\
\text { Correction } \\
\text { Term }\end{array}$ & $\begin{array}{c}\text { Error } \\
\text { Correction } \\
\text { Model }\end{array}$ \\
\hline Rank = r & Rank > r & & & & Constant & Constant \\
\hline 0 & 0 & 0.3517 & $85.67^{*}$ & 53.42 & & \\
\hline 1 & 1 & 0.2601 & $44.50^{*}$ & 34.80 & & \\
\hline 2 & 2 & 0.1394 & 15.88 & 19.99 & & \\
\hline 3 & 3 & 0.0168 & 1.61 & 9.13 & & \\
\hline
\end{tabular}

(1) critical value provided by SAS at $5.0 \%$ level.

Source: Basic data from Oilseeds (Oct. 1995 - Oct. 2003). 
When the analysis of the system involves more than two time series more than two cointegration vectors may exist. According to Dickey, Jansen and Thornton (1994, p. 22) cointegrating

vectors can be thought of as representing constraints that an economic system imposes on the movement of the variables in the system in the long-run.

Consequently, the more cointegrating vectors there are, the "more stable" the system. Other things being the same, it is desirable for an economic system to be stationary in as many directions as possible.

Results obtained from the estimation of the Vector Error Correction Model both in the short- and the long run were incompatible with economic theory a priori expectations, so these results will not be presented here.

In order to confirm the Law of One Price in the international market for soybeans, the restriction that long term parameters $(\beta)^{18}$ for variables LROT, LARG and LUS A are equal to one was imposed. The vector error correction model was estimated again, this time with the restrictions that LROT, LARG and LUSA are equal to one. Because of this imposition, the $\mathrm{H}$ matrix becomes the following (Box 1).

Once the restrictions that

$\beta_{11}=-\beta_{21}=-\beta_{31}=-\beta_{41}$ were

imposed, the vector error correction model was re-estimated, taking into account the restrictions on the long-term parameters that affect the short-term elements $\alpha$.

From the results of the cointegration test it is also possible to check whether the signs of the coefficients are in line with the prediction of economic theory. This is done with the analysis of the coefficients of the variables of the first cointegration equation normalized.

Box 1_ "H" matrix with restrictions imposed on $\beta$ parameters

\begin{tabular}{|c|c|c|}
\hline Variable & Vector 1 & Vector 2 \\
\hline$\angle P B R$ & 1 & 1 \\
\hline LROT & -1 & 1 \\
\hline$L A R G$ & -1 & 1 \\
\hline LUSA & -1 & 1 \\
\hline
\end{tabular}

Source: Adapted from Statistical Analysis Software (SAS).

18 A discussion on restrictions to short and long term parameters is presented in Johansen (1995) and Harris (1995). 
19 The main components of animal ration are corn as source of carbohydrate and soy meal as a relevant source of proteins.
Normalization was based on the estimate of the LBR coefficient, thus the coefficient estimate was set at one. The coefficient for $L B R$ is the system's endogenous variable while $L R O T, L A R G$ and LUS $A$ are exogenous. In such a context, the analysis of the coefficient estimates for LROT, LARG and LUSA in the right column of Table 5 must be carried with inverted signs, since the normalized cointegration equation has all variables on the same side.

Table 5 shows that when the restrictions on the long-term $\beta$ parameters are imposed, short term deviation from equilibrium represented by parameters $\alpha$ are eliminated at a speed of $26.16 \%$ in each period for Brazil against $31.27 \%$ of the soybean prices in Argentina.

Apparently such results were able to detect the characteristics of each market. Unlike Argentina, Brazil shows a significant domestic market for soybeans. Brazil is the largest world exporter of chicken, and soybeans are one of the main components of their feed. As the domestic market is of significant size, one should expect that any short term deviation from equilibrium that may come from the international market would take more time to fade away in the Brazilian market as compared to the Argentine market. The latter being more linked to developments in the international market, it implies a higher sensibility of domestic prices against transitory deviation from equilibrium in external prices due to the absence of a significant domestic market. As compared to Brazil and Argentina, the Rotterdam response to deviations is even slower, at around $21.0 \%$ per period. Soybean prices in Rotterdam tend to react more slowly against prices of this commodity in Brazil and Argentina, for, unlike Brazil and Argentina which are price takers, Rotterdam is a price maker. Soy meal is mainly used as one of the key inputs for animal feed, and the European Union is one of the world's largest producers of pork and beef. It is necessary to observe that, inversely to what occurs in Brazil, European cattle is fed with ration ${ }^{19}$ and confined because of scarcity of land and feed. In Brazil, cattle are grown on large properties and are pasture-fed. Machado and Margarido (2001) used the X12 method and found that prices in Rotterdam show the smallest seasonal variation relative to the other three markets (Brazil, Argentina and the United States), as a result of the alternation of harvesting seasons between the two hemispheres. The European Union faces a continuous supply the whole year, alternating from the northern hemisphere or the southern hemisphere harvesting seasons and that induce a 
pattern of stability in its domestic prices in response to short term deviations in external prices. Finally, the country with the smallest degree of sensibility of correction of short-term deviations was the United States, with a speed of only $2.5 \%$ each period. This relatively small speed of adjustment is related to the fact that, besides being the largest producer and exporter, the United States has a significant domestic market, being a price maker together with Rotterdam. These reasons lie behind the slow fade away of short term deviations in the United States, meaning that its prices are less sensitive to short term variations of international prices relative to other markets.

The estimates of the long term parameter $(\beta)$, with restrictions imposed on them, show that in the long run the Law of One Price works in the

Table 5_Estimates of short and long term coefficients of the Vector Error Correction model (VEC) with restrictions on parameters $\beta$, variables LBR, "LROT", "LARG" and "LUSA", Oct. 1995 to Oct. 2003

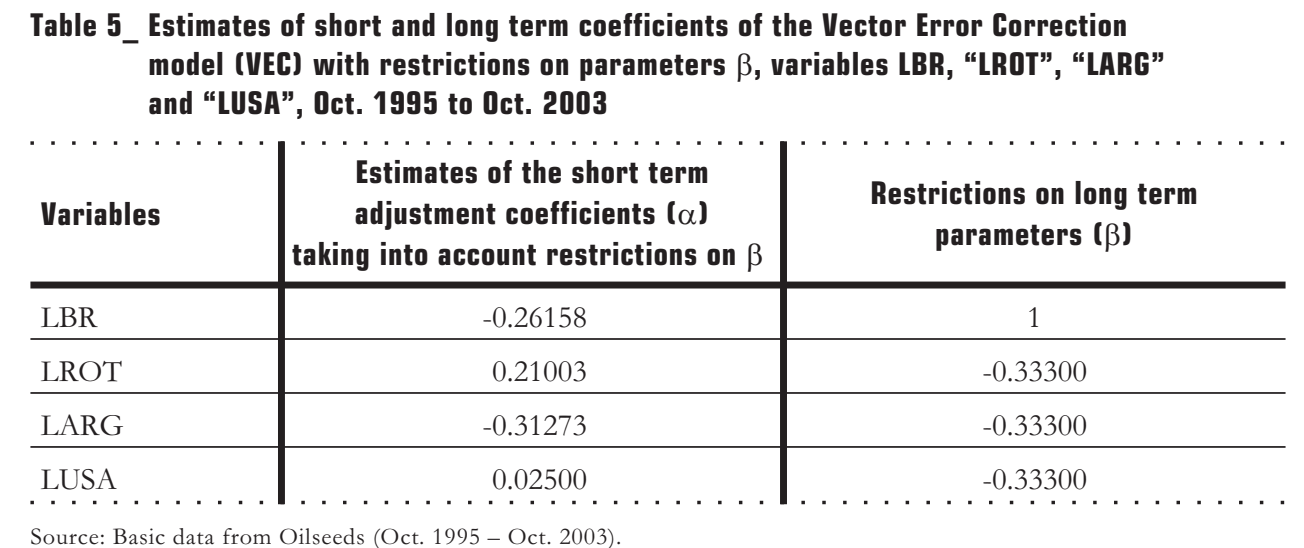

Source: Basic data from Oilseeds (Oct. 1995 - Oct. 2003). international market for soybeans, for it was shown that the sum of these three estimated coefficients $\left(\beta_{21}+\beta_{31}+\beta_{41}\right)$ equals unity $(0.3333+0.3333+0.3333) .^{20}$ Another relevant aspect of the results is the confirmation by this study that all long term estimated coefficients have the same value, thus confirming the working of the arbitrage process in the international market for soybeans. Thus, variations in the international price of soybeans tend to be fully transmitted to prices in Brazil in the long run, so that the elasticity of price transmission is unity. Finally, to confirm that the imposed restrictions are significant, i.e., to validate the Law of One Price, a joint $\chi^{2}$ test was performed on the set of restrictions, $\beta$ taking unity value for LROT, LARG and LUSA.

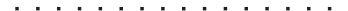

20 Here it is important to note that for VEC and VAR models there is not the traditional distinction between dependent and independent variables. These types of models have all variables as endogenous, thus the variable to be considered dependent needs to be normalized, as its coefficient is fixed as being equal to unity. Because of such normalization, the remaining variables are shifted to the right side of the equation, taking the role of independent variables. Thus, the signal of the restricted coefficients are inverted, so as that the interpretation in Table 5 requires inverting the signals. A plus sign must be read as a minus and conversely. 
Results of the $\chi^{2}$ test show that the probability of Type I Error, of not rejecting the null hypothesis the coefficient of the restricted parameters are jointly significant $\left(\beta_{11}=\beta_{21}=\beta_{31}=\beta_{41}=1\right)$, when it is actually false, lies below $1 \%$. The null hypothesis is accepted against the alternative hypothesis that the restricted parameters are not significant $\left(\beta_{11} \neq 1, \beta_{21} \neq 1, \beta_{31} \neq 1, \beta_{41} \neq 1\right)$, as presented in Table 6 . In economic terms, this means that the Law of One Price holds in the international market for soybeans, since variations in the international price are fully transmitted to domestic prices in Brazil, having unity elasticity of transmission in line with the prediction of economic theory.

We performed tests for exogeneity on the short term parameters $\alpha$, for confirming whether soybean prices in Brazil are influenced by external prices, thus identifying whether variables react to changes in the long run equilibrium. The analysis is conducted between the "dependent" variable and each one of the remaining "independent" variables. On the pairs $L B R$ and LROT the null hypothesis that the soybean prices in Rotterdam are weakly exogenous, or that soybean prices in Brazil do not react to variations in originated in Rotterdam, was rejected, with $42.76 \%$ probability of incurring in Error Type I (not to reject the null hypothesis when it is false). Therefore, the null hypothesis was rejected in favor of the alternative hypothesis, thus the variable soybean price in Rotterdam is not weakly exogenous and prices in Brazil respond (are influenced) by price variations originated in Rotterdam. For Argentina we found the opposite. More precisely, the null hypothesis that soybean prices in Brazil do not react to price variations in Argentina, or that these are weakly exogenous cannot be rejected, for the probability of incurring in Error Type I is below the significance level of $1.0 \%$, at around $0.031 \%$.

Table 6_Johansen cointegration test with restriction for one cointegration vector

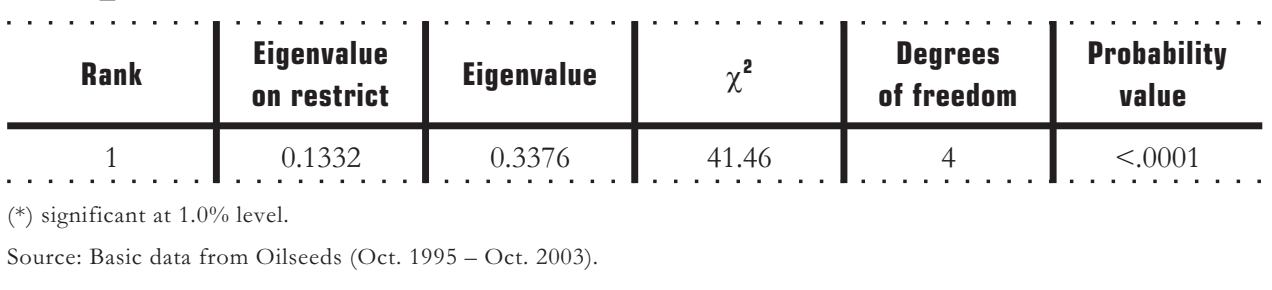


Thus, price variations originating in Argentina do not affect prices in Brazil, the first being weakly exogenous relative to prices in the Brazilian market. Finally, a result similar to that for Rotterdam was found for soybean prices in the United States, or that these are not weakly exogenous, and consequently, prices in Brazil react to price variations in the US market (Table 7). The results that were found in exogeneity tests detected structural features of the international market for soybeans. Both Rotterdam and Chicago are price makers in the world market for soybeans, but it is worthwhile noting that variation in prices in Rotterdam are more significant than variations in US prices on prices in Brazil. This happens because the European Union is a net importer of soybeans, basically used as animal feed, and also because it is the main destination of soybeans exported by Brazil. One should then expect domestic soybean prices in Brazil to be influenced by variations in those two markets. For Argentina, the result also reflects the characteristics of this market, as Argentina, like Brazil, is a price taker in the world market.

Table 8 presents the results on the variance decomposition of forecast errors on the four relevant variables. According to Margarido (2000, p. 132-133),
the variance decomposition of forecast errors gives the dynamic behavior shown by economic variables. In particular, this procedure separates the variance of the forecast errors for each variable in components that may be attributable to each of the remaining endogenous variables, or it states in percentage the effect of an unanticipated shock on the remaining variables of the system.

Table 7_ Exogeneity test on short term parameters ( $\alpha$ ) for variables "LBR”, “LROT”, "LARG” and "LUSA", October 1995 to October 2003

\begin{tabular}{|c|c|c|c|}
\hline Variable & $\chi^{2}$ & Degrees of freedom & Probability value \\
\hline$L B R$ & 0.64 & 2 & 0.7263 \\
\hline LROT & 1.70 & 2 & 0.4276 \\
\hline$L A R G$ & 11.57 & 2 & 0.0031 \\
\hline$L U S A$ & 2.72 & 2 & 0.2573 \\
\hline
\end{tabular}

Source: Basic data from Oilseeds (Oct. 1995 - Oct. 2003). 
Table 8_ Results of the decomposition of variance of the forecast errors in percentage for variables "LBR", "LROT", “LARG” and "LUSA", October 1995 to October 2003

\begin{tabular}{|c|c|c|c|c|c|}
\hline Variable & Lead & "LBR" & "LROT" & "LARG" & "LUSA" \\
\hline \multirow{5}{*}{$L B R$} & 1 & 1.00000 & 0 & 0 & 0 \\
\hline & 3 & 0.99553 & 0.00257 & 0.000408 & 0.00149 \\
\hline & 6 & 0.98781 & 0.00756 & 0.00184 & 0.00278 \\
\hline & 9 & 0.98327 & 0.01025 & 0.00223 & 0.00425 \\
\hline & 12 & 0.98173 & 0.01123 & 0.00221 & 0.00484 \\
\hline
\end{tabular}

Source: Basic data from Oilseeds (Oct. 1995 - Oct. 2003).

In greater detail, according to Margarido et al. (2004, p. 88-89), when using VAR or VEC models one of the key objectives is to assess the effects of individual shocks on the system dynamics, thus, it turns out to be necessary to make some adjustments on the residuals variance-covariance matrix $(\Sigma)$, because it is generally not a diagonal matrix, implying that shocks $u_{1 t}, u_{2 t}, \ldots$, $u_{n t}$ can take place simultaneously with probability different from zero, meaning that they may be contemporaneously correlated. It is then necessary to diagonalize the variance-covariance matrix so as to prevent shocks on a specific variable from contaminating the whole system, thus preventing an analysis of the individual effect of that shock on the variable of interest. The most used procedure is the Cholesky decomposition which allows the researcher to observe the effect on the remaining variables of the model of a unitary shock of one standard deviation, in every period. However, one should notice that, although orthogonalization of the errors through Cholesky decomposition results in a diagonal variance-covariance matrix of innovations (no serial correlation among error terms), it is still an arbitrary method as it attributes common effects. Changing the ordering of equations, the procedure may lead to changes in the impulse-response function, demanding careful analysis of the results.

In other words, according to Bliska (1990, p. 46) one of the main advantages of the orthogonalized innovations on the others is that they are uncorrelated. However, there is a different decomposition for each 
ordering of the variables, and the direction of the effect comes as a consequence of the arbitrary selection of the order of the variables in the analyzed vector. The smaller the contemporaneous covariance (lower correlation between residuals), the smaller the importance of any chosen ordering. Therefore, even when there is no causality between two variables, there may still be effects of a shock in one of them over the other because of the presence of covariance between their respective errors. ${ }^{21}$

Usually the ordering of variable entry is chosen according to the degree of importance. First, the international variables, then macroeconomic variables and last the microeconomic (sector level) variables. As all the variables in this study are international in nature, the order of entry of each one was chosen according to their level of importance for price formation in Brazil. Given that the major destination of Brazilian soybeans is the European Union and that recent studies suggested that the Rotterdam price is the most important factor explaining the behavior of Brazilian prices, this variable was the first to be added. Next, the Argentine price was introduced, since Argentina, besides showing an increasing share in the international market in spite of the United States, is also located in the Southern Hemisphere, being a direct competitor of Brazil. The geographical coincidence between Brazil and Argentina makes harvesting periods similar in the two countries. As a result, harvest estimates in Argentina have an influence on Brazilian prices. Finally, US soy prices were inserted. Again, recent papers demonstrated that the degree of influence of US prices on Brazilian prices is declining over time.

The second column of Table 8 shows the periods expressed in months. In this paper, it is assumed that an unanticipated shock on any of the variables lasts for a maximum period of twelve months.

For variable $L B R$, the third column shows the percentage of variance of forecast errors against unanticipated shocks on this variable, or it evaluates the effect in time of an unanticipated shock on $L B R$ over itself. The $4^{\text {th }}, 5^{\text {th }}$ and $6^{\text {th }}$ columns detail the percentage of variance of forecast errors of $L B R$ that can be attributed to variations in $L R O T, L A R G$ and LUS A, respectively. From Table 8 we can see that 12 months after an unanticipated shock over LBR, there remains only $1.828 \%$ of the variance of forecast errors of LBR that are caused by variables $L R O T(1.123 \%), L A R G(0.221 \%)$
21 Details on the Cholesky decomposition can be found in Enders (2003). 
22 The change in the composition of exports may be related to a process of "reprimarization" of the Brazilian economy as named by Gonçalves (2001, p.13-14). According to the author, "reprimarization may be viewed under two aspects. The first comes because of the loss of international competitiveness of manufactures and the gain in agricultural products exported by Brazil. The second expresses the change in the structure of exports into a higher relative share of agricultural products and a smaller share of manufactures". and LUS A $(0.484 \%)$, while the remaining $98.17 \%$ are caused by itself. Thus, unanticipated shocks on Brazil grain prices are heavily influenced by itself, while the share of influence of the remaining international soybean prices are almost negligible, confirming the hypothesis that Brazil is a price taker in the international market for soybeans.

The results of the variance decomposition of forecast errors of LROT are that one month after an unanticipated shock on that variable, $43.677 \%$ is caused by itself and $56.323 \%$ comes from LBR. Twelve months after the initial shock the already significant influence of $L B R$ rises further to $75.816 \%$, while the participation of LROT falls to $21.483 \%$. The influences of LARG and LUS $A$ are $0.03260 \%$ and $2.66800 \%$ respectively, adding up to a total of only $2.70 \%$ (Table 9 ).

Table 9_ Results of the variance decomposition of forecast errors in percentage for variables "LBR", “LROT", “LARG" and "LUSA", Oct. 1995 to Oct. 2003

\begin{tabular}{|c|c|c|c|c|c|}
\hline Variable & Lead & “LBR” & "LROT" & “LARG” & "LUSA" \\
\hline \multirow{5}{*}{ LROT } & 1 & 0.56323 & 0.43677 & 0 & 0 \\
\hline & 3 & 0.68974 & 0.29941 & 0.000582 & 0.01026 \\
\hline & 6 & 0.73836 & 0.23587 & 0.000282 & 0.0255 \\
\hline & 9 & 0.75198 & 0.22129 & 0.000333 & 0.0264 \\
\hline & 12 & 0.75816 & 0.21483 & 0.000326 & 0.02668 \\
\hline
\end{tabular}

Source: Basic data from Oilseeds (Oct. 1995 - Oct. 2003).
As for Brazil, it is relevant to notice that prior to the Complementary Act \#87, of September 13, 1996, known as Lei Kandir, there was a relative equilibrium between Brazilian exports of grains and soymeal. As noticed by Margarido and Turolla (2003), after that Act the composition of Brazilian exports of the soy chain changed to a smaller quantity of soymeal and stronger sales of grain, as the latter and primary products in general were exempted from taxes.

More specifically,

the exemption of primary and semi-elaborated products caused a change in incentives to export, as compared to the other elements of the value chain. This change may have caused faster expansion of the segments that benefited from the exemption, at least early after the Act came into force (Margarido and Turolla, 2003, p. 11). ${ }^{22}$ 
The results then show that there is a close relationship between soybean prices in Rotterdam and Brazil, as opposed to the relationship between prices in Argentina and the United States. Twelve months after an unanticipated shock on the Rotterdam soybean price, $75.82 \%$ of the Rotterdam price change is explained only by the prices in Brazil. In addition, for Argentina and the United States, again the results detected the international trade structure of the soybeans market.

Twelve months after an unanticipated shock on Rotterdam prices, the percentage share of the decomposition of forecast errors on Argentina is just $0.0326 \%$, quite low as compared to the Brazilian figure.

This possibly reflects not only the fact that Argentine soybeans are genetically modified, ${ }^{23}$ thus subject to import restrictions by the European Union, but also that most of Argentine exports in the soy chain are soymeal, unlike Brazil. And the European Union has barriers on imports on soymeal, while grain is imported without tariffs. The main objective of this policy is the creation of income and employment via incentives for the aggregation of value to take place inside the Union. In turn, the Argentine policy creates incentive for soymeal exports relative to soybeans. According to Freitas et al. (2001, p. 8-9),

\begin{abstract}
Argentina sends $96.0 \%$ of its
production to the external market and keeps only $3.5 \%$ for domestic consumption. That country has in place a mechanism for protection of the local industry called Retenciones, which is designed to keep the raw material in the country by taxing grain exports at a $3.5 \%$ rate. It assures that local processing takes place, consequently raising employment in this chain. The mechanism creates an incentive for oil and soymeal production, without creating similar incentives for consumption. On the other hand, soymeal exports benefit from the Reintegro, a rebate in domestic taxes in the range between $1.4 \%$ and 6.8\%. The mechanism drives Argentine prices downwards, raising their share in the international market.
\end{abstract}

The decomposition of variance of forecast errors for an unanticipated shock on the soybeans in Rotterdam shows that after 12 months only $2.668 \%$ of the Rotterdam price is caused by US prices (Table 9). Such a weak influence apparently has two causes. First, as mentioned earlier, US soybeans are genetically modified, and consequently its imports are limited by the European Union. In addition, the major market for US soybeans is composed of Southeast Asian countries, not the European Union, the latter being mostly supplied by Brazil. Possibly these two factors help explain the ${ }^{23}$ It is important to keep in mind that the European Union imposes restrictions on imports of genetically modified soybeans. Among the major exporters, only Brazil produces conventional soybeans, while the US and Argentina use genetically modified seeds. 
weak relationship between European Union and United States prices.

The decomposition of variance of forecast errors show that one month after the unanticipated shock in Argentine prices only $20.60 \%$ is due to itself while Brazilian prices enter with $78.84 \%$. Rotterdam and US prices show an almost negligible influence of $0.563 \%$ and $0.0 \%$ (Table 10). Twelve months after the shock, Brazil contributes with $95.68 \%$, Rotterdam with $1.902 \%$ and $0.606 \%$ (Table 10).

As in previous cases, the results shown here detected conditions that prevail in the international market for soybeans. The relevant influence of Brazilian prices in the short term on Argentine prices is possibly related to geographical conditions. As these countries are neighbors and more important, are located in the same hemisphere, they have similar harvesting seasons. However, as pointed out by Machado and Margarido (2004), there is a one-month lag between the two countries' crops, with the Brazilian harvest coming one month before that of Argentina. As the second largest world producer, this one-month lag may be part of the explanation of the results of this paper, since crop expectations in Brazil influence not only Brazilian prices but may also have considerable impact on the prices in Argentina. Box 2 depicts the entry times of the harvests of the major producers and exporters, making clear that the US harvesting season is inverse to the southern hemisphere countries, which show a high degree of time coincidence.

Table 10_ Results of the variance decomposition of forecast errors in percentage for variables "LBR", "LROT", "LARG" and "LUSA", October 1995 to October 2003

\begin{tabular}{|c|c|c|c|c|c|}
\hline Variable & Lead & “LBR” & “LROT” & “LARG" & "LUSA" \\
\hline \multirow{5}{*}{$L A R G$} & 1 & 0.7884 & 0.00563 & 0.20597 & 0 \\
\hline & 3 & 0.90427 & 0.00338 & 0.08823 & 0.00412 \\
\hline & 6 & 0.93425 & 0.0173 & 0.03873 & 0.00973 \\
\hline & 9 & 0.95023 & 0.01848 & 0.02433 & 0.00697 \\
\hline & 12 & 0.95681 & 0.01902 & 0.01811 & 0.00606 \\
\hline
\end{tabular}

Source: Basic data from Oilseeds (Oct. 1995 - Oct. 2003). 
Box 2_Soybean crop and trade time

\begin{tabular}{|c|c|c|c|c|c|c|c|c|c|c|c|c|}
\hline & Jan. & Feb. & Mar. & Apr. & May & Jun. & Jul. & Aug. & Sep. & Oct. & Nov. & Dec. \\
\hline USA & $\mathrm{H}$ & $\mathrm{H}$ & $\mathrm{H}$ & & & & & & $\mathrm{H}$ & $\mathrm{H}$ & $\mathrm{H}$ & $\mathrm{H}$ \\
\hline BR & & & $\mathrm{H}$ & $\mathrm{H}$ & $\mathrm{H}$ & $\mathrm{H}$ & $\mathrm{H}$ & $\mathrm{H}$ & $\mathrm{H}$ & & & \\
\hline ARG & & & & $\mathrm{H}$ & $\mathrm{H}$ & $\mathrm{H}$ & $\mathrm{H}$ & $\mathrm{H}$ & $\mathrm{H}$ & $\mathrm{H}$ & & \\
\hline
\end{tabular}

$\mathrm{H}=$ harvest period

Source: Machado and Margarido (2004).

As mentioned earlier, the low influence of Rotterdam on Argentina may be related to the fact that most of the Argentine exports are soymeal, not soybeans; and also that the European Union places tariffs and non-tariff barriers on genetically modified soybeans, precisely the variety produced by Argentina.

The key reasons for the weak influence of US prices on Argentina may be related to different entry periods in the market, despite being a price taker, as opposed to what occurs between Brazil and Argentina. Box 2 shows that the US harvest goes from September to March, while the Argentine harvest is from April to October. This may be behind the weak interaction between both prices in the short term.

One last task is to analyze effects of shocks of US prices on the remaining variables. One month after such a shock, the decomposition of variance shows that $37.655 \%$ is due to itself, $59.18 \%$ to Brazil's prices, $1.888 \%$ to Argentina and $1.276 \%$ to Rotterdam. Twelve months after the shock, the own effect of the US price falls to only $3.641 \%$, while the Brazilian influence rises to $92.01 \%$, Rotterdam goes to $4.151 \%$ and Argentina only $0.198 \%$ (Table 11).

The strong relationship between prices in the US and Brazil is possibly related to the share of both countries in global production and exports. However, data in Box 2 may offer some additional explanation: in March, when the US season is ending, Brazilian soybeans start entering the market. In turn, when the Brazilian season is ending, the US period begins. By the end of the US harvest, stocks decline and agents turn their expectations to the Brazilian harvest, which is starting to trade. Thus, prices stay highly connected. 
Table 11_Results of the decomposition of variance of forecast errors in percentage for variables "LBR", “LROT", "LARG" and "LUSA", October 1995 to October 2003

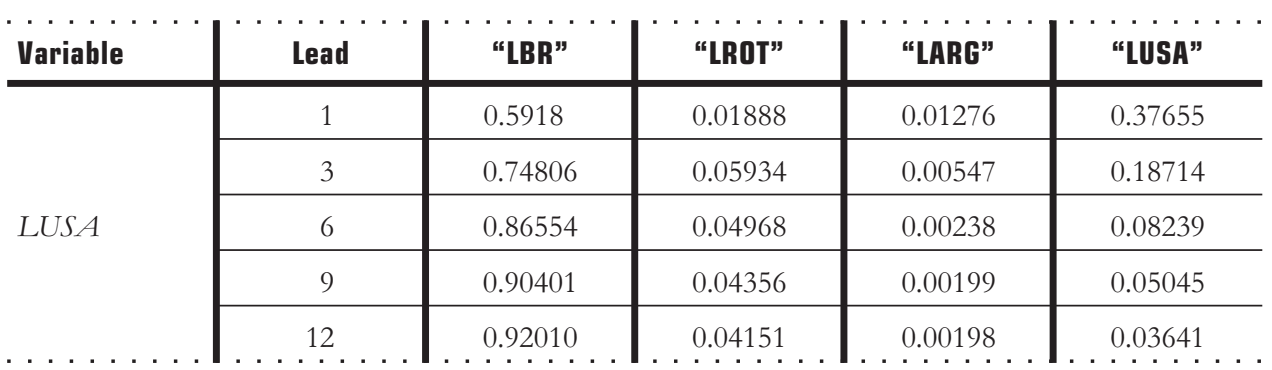

Source: Basic data from Oilseeds (Oct. 1995 - Oct. 2003).

In the short term, the low share of Rotterdam prices relative to US prices possibly comes from the fact that the main market for US soybeans is in Asia, while Rotterdam is basically supplied by Brazil. Against that background, the Rotterdam market may be viewed as residual for US producers, thus explaining its small contribution for the formation of US prices.

The small contribution of Argentina for US prices possibly reflects the facts already mentioned, namely that the US is a price maker while Argentina and Brazil are price takers, and also that Argentina gives incentives to soymeal exports relative to soybeans. An additional explanation for this phenomenon may be found in the natural switch of harvesting seasons between the major producers. As the end of the US season coincides with the beginning of the Brazilian season, which in turn comes one month before the Argentine season, expectations for Brazilian prices are key to price formation in the US low season. That is in line with the conclusion that Brazilian prices contribute heavily to the formation of US prices while the effects of Argentine prices on the US are attenuated.

The next step was to calculate the impulse-response function. It shows how a shock in a variable influences the other variables of the system, thus helping to identify not only the size of the impact but also its time profile. As in the case of variance decomposition of forecast errors, it is possible to verify how impacts in each individual variable are transmitted to the remaining variables in the model. In this study, only the impacts of international prices 
on Brazilian prices are deemed to be relevant and are presented below.

Any unanticipated shock in Rotterdam induces an increase in Brazilian prices. This upward path goes in four separate phases. Initially, Brazilian prices increase rapidly up to one month after the shock. Between the $1^{\text {st }}$ and the $2^{\text {nd }}$ month prices keep increasing, however at a lower pace, reaching a maximum and stabilizing between the $5^{\text {th }} / 6^{\text {th }}$ month after the initial shock (Figure 1). This time path apparently reflects the fact that Rotterdam is a price maker and Brazil is a price taker in spite of being the second largest soybean producer and exporter. Another relevant aspect is that most of the Brazilian production goes to the European Union through its main gate, the Port of Rotterdam.

A shock in US prices causes, at first, a fall in Brazilian prices up to the first month. From that point onwards, the path is inverted so that prices slowly move upwards up to the $5^{\text {th }} / 6^{\text {th }}$ month, and they stabilize at that point, similar to the preceding case (Figure 1). Again, this is consistent behavior, since the US, like Rotterdam, is a price makers. The initial price decline in Brazil as a response to a shock in US prices is possibly related to the different harvesting seasons that were earlier shown in Box 2. By the end of the US season in March, Brazilian soybean production starts entering in the market. Initially there is an excess of supply in that moment, temporarily reducing prices in Brazil. Later, the quantity supplied by the US declines and only Brazil offers soybeans, since Argentina, although it has similar harvesting period, offers more soymeal than grain. Thus Brazil's prices tend to increase up to the $5^{\text {th }}$ month.

A shock in Argentine prices influence Brazil's in three steps. Brazilian prices increase up to the first month and then reverse downwards to the point where they stabilize by the $5^{\text {th }} / 6^{\text {th }}$ month, inversely to the preceding cases. Since harvesting seasons are almost equivalent for both countries, a shock in the Argentine price coming from international demand, early in the southern hemisphere harvesting season, implies a situation in which the international market sees lack of supply. International demand shifts to the southern hemisphere. Initially, the initial scarcity causes Brazilian prices to follow Argentina's. The second step is when quantities supplied by Brazil and Argentina tend to increase and Brazilian prices head downwards to reach a minimum at the $5^{\text {th }}$ month after the shock and stabilize there. 


\section{Figure 1_Elasticity of the impulse-response function, effects of shocks of "LROT", "LARG" and "LUSA" on "LBR"}

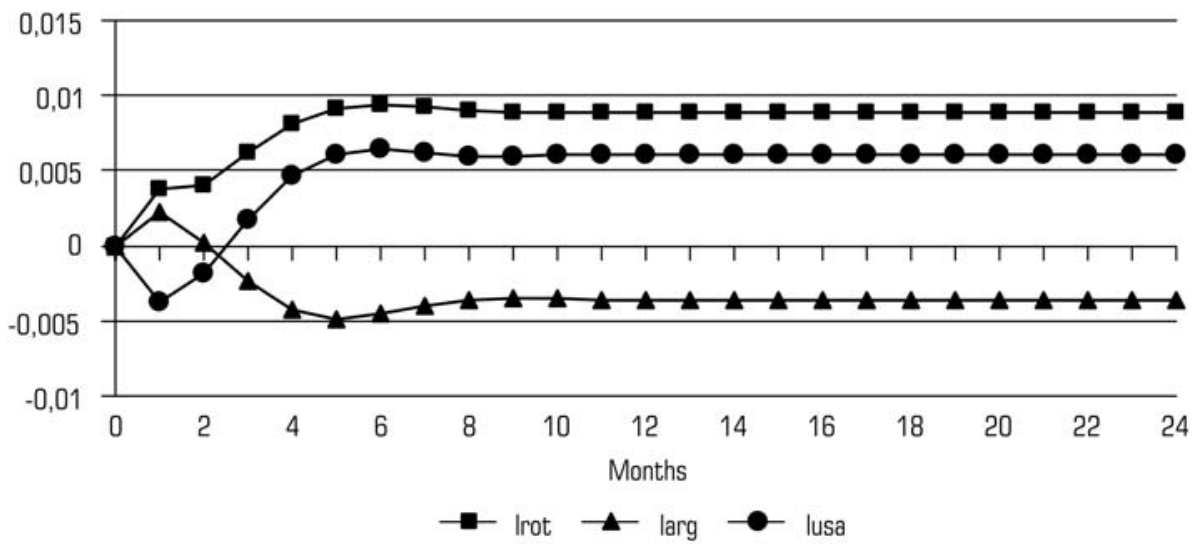

Source: Basic data from Oilseeds (Oct. 1995 - Oct. 2003).

\section{Conclusion}

This paper investigates the price transmission in the world market for soybeans using time series econometrics models. The theoretical model developed by Mundlack and Larson (1992) is based on the Law of One Price, which assumes price equalization across all local markets in the long run and allows deviations in the short run. The international market was characterized by three relevant soybean prices: Port of Rotterdam, Argentina and the United States. The paper estimates the elasticity of transmission of these prices into soybean prices in Brazil. Causality and cointegration tests were performed in order to identify whether there is significant long-term relationship among these three variables. Impulse-response function was also calculated, and error variance decomposition was forecast to analyze the transmission of variations over time in the international prices over Brazilian prices. An exogeneity test was also carried out to check whether the variables respond to short term deviations from equilibrium values. Results confirmed the Law of One Price in the long run. In line with many studies, this paper showed that the speed of adjustment of prices in Brazil and Argentina can be seen as price 
takers since their response to shocks is slower than in the United States, the latter being a price maker.

A further research step may be to make the international market more complete by incorporating the Chinese soybean prices. Although these were relevant to the study, a time series was not available.

An interesting conclusion was reached when the pattern of the impulse response functions was compared to the timing of crop and trade in Brazil, Argentina and the United States. The pattern of these functions is as follows:

_ Brazilian prices respond to a shock in US prices with decline in the first month and a rise above the initial level up to the $5^{\text {th }} / 6^{\text {th }}$ month, when they stabilize;

_ Brazilian prices respond to a shock in Rotterdam prices with a steady increase up to the $5^{\text {th }} / 6^{\text {th }}$ month when they stabilize, but the increase is more rapid in the first month; _ Brazilian prices respond to a shock with an increase in the first month, and a decline below the initial level up to the $5^{\text {th }} / 6^{\text {th }}$ month when they stabilize. This pattern is opposite the pattern of response to a shock in US prices.

These seasonal differences may help explain the pattern of the response of Brazilian prices to shocks in the international market. Two interesting points can be made:

1. the response from shocks in the United States is opposite to the response from shocks in Argentina because harvests in the two hemispheres occur in different periods;

2. the one-month lag between Brazilian and Argentine harvests may contribute to explain a turning point in the impulse-response function that occurs one month after the shock. Even the Rotterdam shock causes a more rapid increase of Brazilian prices in the first month than in the subsequent months.

This timing pattern was investigated in Machado and Margarido (2004) and in this paper, and merits further research. 


\section{References}

AGUIAR, Danilo R. D.; BARROS, Geraldo S. A. C. causalidade e assimetria na transmissão de preços de soja e derivados no Brasil nos anos oitenta. Estudos Econômicos, São Paulo, v. 21, n. 1, p. 89-103, jan.-abr. 1991.

AKAIKE, H. Canonical correlations analysis of time series and the use of an information criterion. In: Advances and case studies in system identification. New York: Academic Press, 1976. p. 27-96.

BANERJEE, Anindya et al. Cointegration, error-correction, and the econometric analysis of non-stationary data. New York: Oxford University Press, 1993. 329p. (Advanced Texts in Econometrics).

BARROS, Geraldo S. A. C. Preços de commodities agrícolas e o câmbio flexível. Piracicaba: ESALQ, 1990. 36p.

BARROS, Geraldo S. A. C.; BURNQUIST, Heloisa L.

Causalidade e transmissão de preços agrícolas entre níveis de atacado e varejo. In:

ENCONTRO LATINO

AMERICANO DA ECONOMETRIC SOCIETY, 7. São Paulo, 1987. Anais... São Paulo, 1987. p. 175-190.
BLISKA, Flávia M, de Mello. Formação de preços de carne bovina: uma aplicação do modelo de auto-regressão vetorial. Agricultura em São Paulo, v. 37, n. 3, p. 41-59, 1990.

CONAB. Exportações brasileiras principais produtos de origem agropecuária. Available at <www. conab.gov.br/download/indicado res/0205-balanca-exportacao. pdf $>$ accessed on July 15, 2004.

DICKEY, David A.; FULLER, Wayne A. Likelihood ratio statistics for autoregressive time series with a unit root.

Econometrica, v. 49, n. 4, p. 1057-1072, jul. 1981.

DICKEY, David A.; FULLER, Wayne A. Distribution of the estimators for autoregressive time series with unit root. Journal of The American Statistical Association, v. 74 n. 366, p. 427-431, Jun. 1979.

DICKEY, D. A.; JANSEN, D. W.; THORNTON, D. L. A primer on cointegration with application to money and income. In: RAO, B. B. Cointegration for applied economists. New York: ST. Martin's Press, 1994. p. 9-45.

ENDERS, Walter. Applied Econometric Time Series. United States, IE-Wiley, second edition, 2003. 480p.
ENGLE, Robert F.; GRANGER, C. W. J. Long-run economic relationship: readings in cointegration. New York: Oxford University Press, 1991. 301p. (Advanced texts in econometrics).

FREITAS, Silene M.;

MARGARIDO, Mario A.; BARBOSA, Marisa Z.; FRANCA, Terezinha J. F. Análise da dinâmica de transmissão de preços no mercado internacional de farelo de soja, 1990-99.

Agricultura em São Paulo, v. 48, n. 1; p. 1-20, 2001.

\section{GONCALVES, R}

Competitividade internacional e integração regional: a hipótese da inserção regressiva. Revista de Economia Contemporânea. Rio de Janeiro, v. 5, n. especial, p. 13-34, 2001

GRANGER, C. W. J. Investigating causal relations by econometric models and cross-spectral methods. Econometrica, v. 37, p. 424-438, 1969.

\section{HARRIS, Richard I. D.}

Cointegration analysis in econometric modelling. London: Prentice Hall, 1995. 176p.
JOHANSEN, Soren.

Likelihood-based inference in cointegrated vector auto-regressive models. New York: Oxford University Press, 1995. 267p. (Advanced Texts in Econometrics).

JOHANSEN, Soren; JUSELIUS, Katarina. Maximum likelihood estimation and inference on cointegration with applications to the demand for money. Oxford Bulletin of Economics and Statistics, v. 52, n. 2, p. 169-210, 1990.

KRUGMAN, Paul R.; OBSTFELD, Maurice. International economics: theory and policy. 4. ed., Massachusetts: Addison Wesley, 1997. 766p.

MACHADO, Eduardo L. ; MARGARIDO, Mario A. Seasonal price transmission in soybean international market: the case of Brazil and Argentina. Pesquisa e Debate, v. 12, n. 1 , p. 92-106, 2001.

MACHADO, Eduardo L.; MARGARIDO, Mario A. Evidences of seasonal price transmission in soybean international market. Economia Aplicada, v.8, n.1, p.127-141, jan.-mar. 2004. 
MACKINNON, James G. Critical values for cointegration tests. In: ENGLE, R. F.; GRANGER, W. J. Long-run economic relationships: readings in cointegration. New York: Oxford University Press, 1991. p. 267-276.

MAFIOLETTI, Robson L. Formação de preços na cadeia agroindustrial da soja na década de 90. Revista de Economia e Sociologia Rural, v. 39, n. 4 , p. $9-25,2001$

MARGARIDO, Mario A.; SOUSA, Eduardo L. L.; BARBOSA, Marisa Z.; FREITAS, Silene M. Transmissão de preços no mercado internacional do grão de soja: uma aplicação da metodologia de séries temporais. In: CONGRESSO BRASILEIRO DE ECONOMIA E

SOCIOLOGIA RURAL, 37., Foz do Iguaçu, 1999. Anais... Brasília: SOBER, 1999.

MARGARIDO, Mario A; SOUSA, Eduardo L. L. Formação de preços da soja no Brasil. Agricultura em São Paulo, v. 45, n. 2, p. 52-61, 1998.

MARGARIDO, Mario A.; TUROLLA, Frederico A.; FERNANDES, Jocelynne M. Análise da elasticidade de transmissão de preços no mercado internacional de soja. Pesquisa e Debate, v. 12, n. 2 , p. 5-40, 2001
MARGARIDO, Mario A.; TUROLLA, Frederico A. Previsão de preços no mercado internacional de grão de soja. Informações Econômicas, São Paulo, v. 33 , n. 1, jan. p. 7-17, 2003

MARGARIDO, Mario A.;

BUENO, Carlos R. F.;

MARTINS, Vagner A.;

CARNEVALLI, Luciana B.

Análise dos efeitos de preços e câmbio sobre o preço do óleo de soja na cidade de São Paulo: uma aplicação do modelo VAR.

Pesquisa e Debate, v. 15, n. 1, p. 69-106, 2004.

MUNDLACK, Yair ; LARSON, Donald F. On the transmission of world agricultural prices. The World Bank Economic Review, v. 6, n. 1, p. 399-422, 1992.

\section{OSTERWALD-LENUM,}

Michael. A note with quantiles of asymptotic distribution of the maximum likelihood cointegration rank test statistics. Oxford Bulletin of Economics and Statistics, v. 54, n. 3, p. 461-472, 1992.

PERRON, Pierre. Trend, unit root and structural change in macroeconomic time series. In: RAO, B. Bhaskara. Cointegration for the applied economist. New York: ST. Martin's Press, 1994. p. 113-146.

PINO, Francisco A.; ROCHA, Marina B. Transmissão de preços de soja no Brasil. Revista de Economia e Sociologia Rural. Brasília, v. 32, n. 4, P. 345-361, out./dez. 1994.
USDA. Oilseeds: World Market and Trade. Washington: USDA, $1995 / 2003$.

USDA. Oilseeds: World Market and Trade. Washington, Nov. 1997. p. 13.

USDA. Oilseeds: World Market and Trade. Washington, Dec. 1999. p. 11.

USDA. Oilseeds: World Market and Trade. Washington, Jan. and Dec. 2003. p. 9.

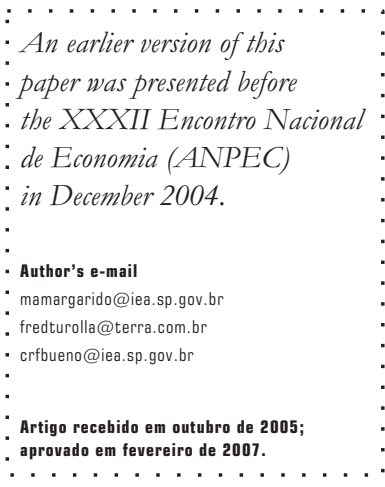

